\title{
Serum Immunoglobulin Paraprotein in Patients with Chronic Lymphocytic Leukemia
}

\author{
HOSNY B. HAMED, M.D.*; ASMAA M. ZAHRAN, M.D.*; MOHAMED Z. ABD EL-RAHMAN, M.D.** and \\ FATMA EL-ZAHRAA A. RASHED, M.Sc.*
}

The Department of Oncological Clinical Pathology, South Egypt Cancer Institute* and The Department of Clinical Pathology, Faculty of Medicine**, Assiut University

\begin{abstract}
Background: Chronic Lymphocytic Leukemia (CLL) is the most common chronic lympho-proliferative disorder. This study was done to explore the frequency of serum Immunoglobulin (Ig) paraprotein in patients with CLL and its correlation with other prognostic factors as expression of CD38 and zeta-chain-associated protein kinase 70 (ZAP70) on malignant lymphocytes.
\end{abstract}

Aim of Study: To study the frequency of serum immunoglobulin paraprotein in patients with CLL and its correlation with other prognostic factors as expression of CD38 and ZAP70 on malignant lymphocytes.

Patients and Methods: Clinico-hematological profiles were done to 30 CLL patients. Serum Protein Electrophoresis (SPE) and Immunofixation Electrophoresis (IFE) were performed to measure serum Ig paraprotein. ZAP-70 and CD 38 were tested by flow cytometry.

Results: In this study CLL patients were classified according to modified Rai staging system into: Low risk $10 \%$, intermediate risk $40 \%$ and high risk $50 \%$. Four CLL patients $(13.4 \%)$ had monoclonal gammopathy (M-band), the type of $\mathrm{M}$-band in the 4 patients was IgG-Kappa. One patient (3.3\%) had diffuse band (polyclonal gammopathy). ZAP-70 and CD 38 positivity were detected in 7 patients $(23.3 \%)$ and 15 patients $(50 \%)$, respectively. There was significant relation between presence of Ig paraprotein in CLL patients and ZAP 70 expression $(p=0.034)$. On the other hand there was no relation between presence of M-band in CLL patients and CD38 expression nor modified Rai staging system.

Conclusion: Monoclonal gammopathy was found in $13.4 \%$ of CLL patients. The detection of Ig paraprotein might be applied for the assessment of prognosis in patients with CLL.

Key Words: Chronic lymphocytic leukemia - Immunoglobulin paraprotein - Prognosis - CD38-ZAP-70.

Correspondence to: Dr. Hosny B. Hamed, The Department of Oncological Clinical Pathology, South Egypt Cancer Institute, Assiut University

\section{Introduction}

CHRONIC Lymphocytic Leukemia (CLL) is a monoclonal expansion of small mature B lymphocytes accumulating in the peripheral blood, bone marrow, and lymphoid organs. CLL is one of the most common types of leukemia in the Western world, however, infrequent in the Eastern. It is the most common types of leukemia diagnosed in adult [1]. CLL cells are positive for monotypic surface immunoglobulin (dim intensity), CD5, CD19, CD20 (dim intensity) and CD23 and usually negative for CD22, CD79b and FMC-7 [2]

The limitation of clinical staging systems (Rai and Binet staging systems) in CLL, which fail to identify early-stage patients who most likely to progress, has led to the search for new prognostic markers with highly predictive capabilities like thymidine kinase, beta2-microglobulin (B2-M), CD38, zeta-chain-associated protein kinase 70 (ZAP70) and detection of monoclonal gamopathy [3].

Expression of CD38 on CLL cells has been shown to be increased in more proliferative clones. There is a close association between CD38 expression and increased Ki-67 proliferation index along with increased ZAP70 positivity [4].

Serum immunoglobulin paraprotein can be detected in a subset of patients with CLL by Serum Protein Electrophoresis (SPE) and immunofixation electrophoresis (IFE). The World Health Organization (WHO) classification recognizes that a "small M component" can be found in some patients with CLL, but no mention is made about the fre- 
quency of this occurrence or the range of serum paraprotein levels in patients with CLL. An earlier study reported that patients with CLL with Immunoglobulin (Ig) paraproteinemia had an inferior survival compared with patients with CLL without serum paraprotein. However, other studies have not confirmed this observation. Therefore, how does the serum Ig paraprotein actually affect the CLL patients' survival is still unknown [5].

\section{Patients and Methods}

The study was done on 30 CLL patients and 20 sex and age matched control. Those patients were presented to South Egypt Cancer Institute Assiut University Hospital in the period between December 2014 and May 2016. The study was approved by the Institutional Review Board of Faculty of Medicine, Assiut University. An informed written consent was taken from of all cases and controls.

\section{All patients and controls were subjected to:}

- Thorough history taking and clinical examination, with careful assessment of clinical signs relevant to leukemia as hepatomegaly, splenomegaly, lymphadenopathy.

- Complete blood picture were performed by the fully automated blood counters Ruby Cell Dyn (American, Serial number: 36026BG) and Cell Dyn 1700 (American, Serial number: 513554). Blood Films were stained with Leishman stain, and were used for morphological identification of the differential count.

- Liver function tests, kidney function tests and estimation of LDH were performed by Cobas integra 400 plus (Swiss, Serial number: 500558).

- Bone marrow examination.

- Immunophenotyping analysis was done by multicolor flow cytometry (FACSCaliber, BD Biosciences-San Jose, CA, USA, serial number E5140). Foreward scatter and side scatter histogram were made to detect the lymphocyte population. Lymphocytes were then gated for further analysis of different monoclonal antibodies as CD5, CD10, CD19, кappa, lamda, FMC7, CD23, CD3, CD38 and Zap70.

Immunophenotyping diagnosis of our CLL patients was done according to scoring system [6]

- Serum protein electrophoresis and acid blue immunofixation: Serum sample were collected and stored in $-20^{\circ} \mathrm{C}$ until analysis. SPE was used as a screening test, while IFE was for confirmation and isotype identification. Pretty Interlab protein electrophoresis analyser (Italy, serial number 38405301) automatically performed all the steps of the analytical procedure in SPE: After application of the samples on the agarose gel plate, electrophoretic migration, gel denaturation, gel staining and de-staining and final gel drying were done.

Immunofixation was done after the electrophoretic migration by application of the fixative solution and the antisera, gel incubation at $20^{\circ} \mathrm{C}$ and gel blotting at $40^{\circ} \mathrm{C}$.

\section{Statistical analysis:}

Statistical analysis was carried out using SPSS statistical software Version 18. Qualitative data are expressed frequency and percentage; quantitative data are expressed by mean \pm Standard Deviation of mean (SD). Comparisons between variables were performed using the chi-square test and independent samples $t$-test. $p$-value $<0.05$ was considered significant.

\section{Results}

Fig. (1) shows the distribution of CLL patients according to modified Rai staging system. Table (1) show the base line characteristic of CLL patients and the controls.

The expression of CD38 on malignant lymphocytes was detected in 15 patients $(50 \%)$ with mean expression of $64.84 \pm 23.60$. However, the expression of ZAP70 on malignant lymphocytes was detected only in 7 patients (23.3\%) with mean expression of $57.98 \pm 23.43$ as in Fig. (2).

In the present study, 4 CLL patients (13.4\%) had monoclonal gammopathy (M-band), the type of M-band in the 4 patients was IgG-Kappa Figs. $(3,4)$. One patient $(3.3 \%)$ had diffuse band (polyclonal gammopathy).

There was significant relation between presence of immunoglobulin paraprotein in CLL patients and ZAP 70 expression with $p$-value $=0.034$. On the other hand there was no significant relation between presence of M-band in CLL patients and CD38 expression. Also there was no significant relation between modified Rai staging system and the presence of M-band as shown in Tables $(2,3)$. 


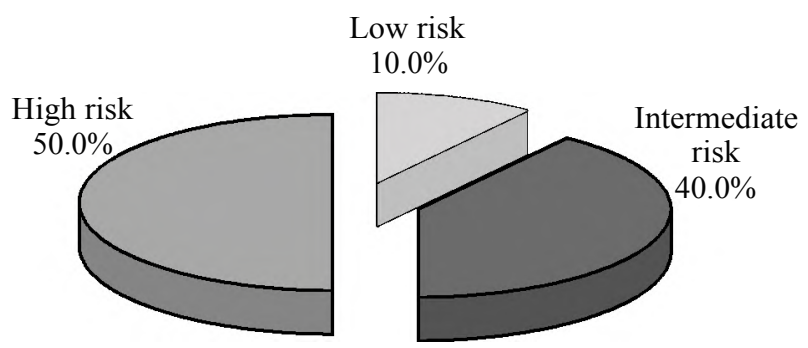

Fig. (1): The distribution of studied patients according to Modified Rai staging system.

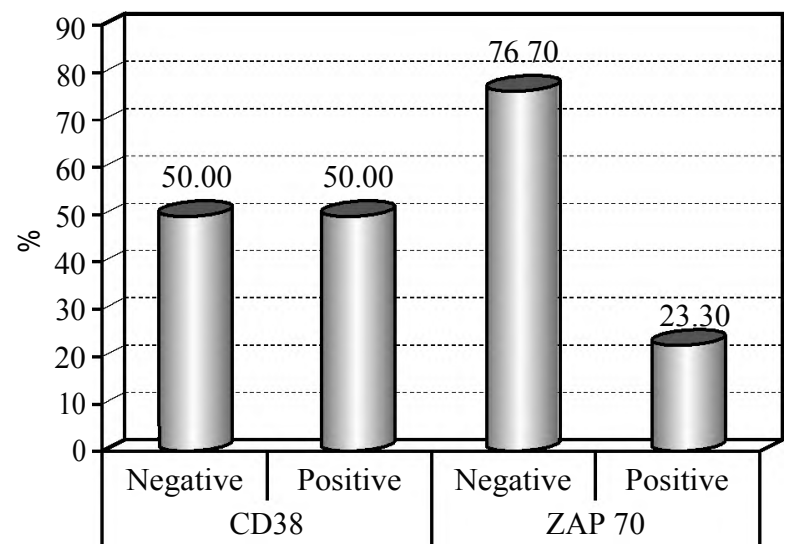

Fig. (2): Expression of CD38 and ZAP 70 on malignant lymphocytes in CLL patients.

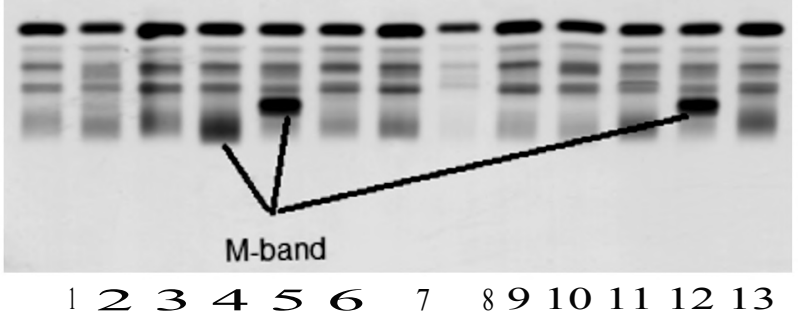

Fig. (3): Serum protein electrophoresis strip showing M-band in our studied CLL patients.

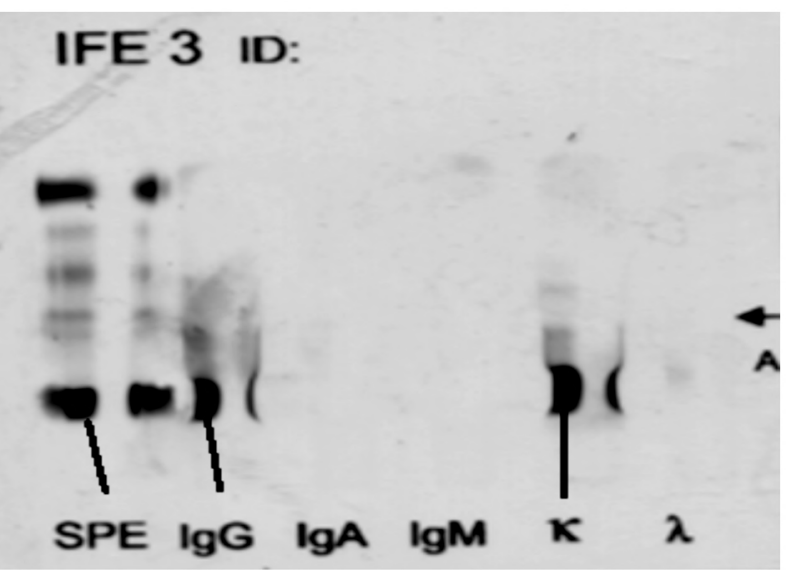

Fig. (4): Immunofixation strip of one of our studied CLL patients showing M-band in SPE, the type of the Mband is IgG kappa.
Table (1): Baseline characteristic of CLL patients and the controls.

\begin{tabular}{llll}
\hline & \multicolumn{1}{c}{$\begin{array}{c}\text { Patients } \\
(\mathrm{n}=30)\end{array}$} & \multicolumn{1}{c}{$\begin{array}{c}\text { Control } \\
(\mathrm{n}=20)\end{array}$} & $\begin{array}{c}p \text { - } \\
\text { value }\end{array}$ \\
\hline Age (years) & $61.53 \pm 12.03$ & $58.85 \pm 10.17$ & 0.416 \\
Sex & $17 / 13$ & $12 / 8$ & 0.815 \\
Hemoglobin $(\mathrm{gm} / \mathrm{dL})$ & $10.64 \pm 1.90$ & $12.01 \pm 1.17$ & 0.007 \\
Platelets $\left(\mathrm{X} 10^{9} / \mathrm{L}\right)$ & $151.51 \pm 78.98$ & $256.00 \pm 93.42$ & $<0.001$ \\
WBCs $\left(10^{9} / \mathrm{L}\right)$ & $101.10 \pm 140.34$ & $6.91 \pm 2.41$ & $<0.001$ \\
PB lymphocytes $(\%)$ & $74.13 \pm 25.88$ & $33.30 \pm 6.01$ & $<0.001$ \\
BM lymphocytes $(\%)$ & $73.90 \pm 25.49$ & & \\
Total protein $(\mathrm{g} / \mathrm{L})$ & $63.63 \pm 11.33$ & $68.10 \pm 4.25$ & 0.165 \\
ALP $(\mathrm{U} / \mathrm{L})$ & $114.50 \pm 60.38$ & $73.55 \pm 10.63$ & 0.002 \\
LDH (U/L) & $495.23 \pm 309.44$ & $314.25 \pm 78.59$ & 0.004 \\
Urea (mg/dL) & $31.17 \pm 5.13$ & $33.60 \pm 6.82$ & 0.167 \\
Creatinine (mg/dL) & $0.76 \pm 0.13$ & $0.77 \pm 0.17$ & 0.881 \\
\hline
\end{tabular}

Independent samples $t$-test.

Significant $p$-value $<0.05$.

Data expressed as mean \pm SD. BM : Bone Marrow.

WBC: White Blood Cell. ALP : Alkaline Phosphatase.

PB : Peripheral Blood. LDH : Lactate Dehydrogenase.

Table (2): Relation between the expression of CD38 and ZAP 70 and the pattern of protein electrophoresis in CLL patients.

\begin{tabular}{|c|c|c|c|c|c|c|c|}
\hline & \multicolumn{6}{|c|}{$\begin{array}{l}\text { Protein electrophoresis pattern } \\
\text { and immunofixation }\end{array}$} & \multirow{3}{*}{$\begin{array}{c}p- \\
\text { value }\end{array}$} \\
\hline & \multicolumn{2}{|c|}{$\begin{array}{l}\text { Normal } \\
\text { pattern } \\
(n=25)\end{array}$} & \multicolumn{2}{|c|}{$\begin{array}{c}\text { M-Band } \\
(\operatorname{IgG}-\text { Kappa) } \\
(n=4)\end{array}$} & \multicolumn{2}{|c|}{$\begin{array}{c}\text { Diffuse band } \\
\text { (polyclonal) } \\
(\mathrm{n}=1)\end{array}$} & \\
\hline & No. & $\%$ & No. & $\%$ & No. & $\%$ & \\
\hline \multicolumn{8}{|l|}{ CD38: } \\
\hline Negative & 13 & 52.0 & 2 & 50.0 & 0 & 0.0 & 0.624 \\
\hline Positive & 12 & 48.0 & 2 & 50.0 & 1 & 100.0 & \\
\hline \multicolumn{8}{|l|}{ ZAP70: } \\
\hline Negative & 21 & 84.0 & 2 & 50.0 & 0 & 0.0 & $0.034 *$ \\
\hline Positive & 4 & 16.0 & 2 & 50.0 & 1 & 100.0 & \\
\hline
\end{tabular}

Chi-square test.

Significant $p$-value $<0.05$.

M-Band : Monoclonal Band.

CD : Clusters of Differentiation.

ZAP70 : Zeta-chain-Associated Protein kinase 70

Table (3): Relation between the protein electrophoresis and immunofixation pattern and modified Rai staging system in CLL patients.

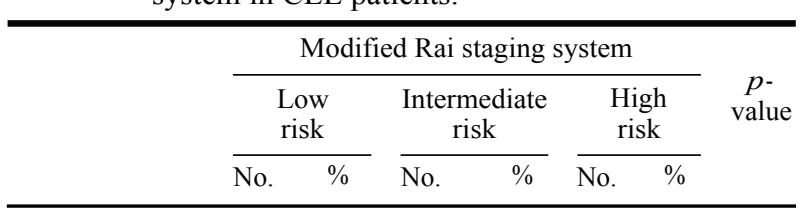

Protein

electrophoresis

and

immunfixation:

$\begin{array}{llllllll}\text { - Normal Pattern } & 3 & 100.0 & 10 & 83.4 & 12 & 80.0 & 0.698\end{array}$

$\begin{array}{lllllll}\text { - M-Band (IgG- } & 0 & 0.0 & 1 & 8.3 & 3 & 20.0\end{array}$

Kappa).

$\begin{array}{lllllll}\text { - Diffuse band } & 0 & 0.0 & 1 & 8.3 & 0 & 0.0\end{array}$

(polyclonal).

M-Band: Monoclonal Band.

Chi-square test

Significant $p$-value $<0.05$ 


\section{Discussion}

Although M-protein secretion is typically a feature of plasma cell dyscrasias, monoclonal gammopathy has been recognized in a wide variety of lymphoproliferative disorders. It has been described in patients with B-CLL, well-differentiated lymphoma, Burkitt's lymphoma and other histological subtypes of lymphomas [2].

The expression of ZAP 70 on malignant lymphocytes was detected in $23.3 \%$ of our CLL patients. This result is near the result found by Morabito et al., who reported that ZAP-70 was positive expressed in $34.9 \%$ of all studied CLL cases [7].

Also, Del Principe et al., found that ZAP-70 was positive expressed in $36 \%$ of all CLL cases [8]. Otherwise, other study done by Cruse et al., and found that ZAP-70 expression was positive in (64.7\%) of CLL cases [9]. In contrast, Deaglio et al., reported that ZAP-70 expression was positive in $(9.52 \%)$ of their studied CLL patients [10]. This variation in the expression of ZAP-70 in CLL patients between our results and previous studies may be due to the low number of our studied patients and also indicate that more large study is required.

Regarding CD38 expression, $50 \%$ of our CLL patients were $\mathrm{CD} 38$ positive. This result was nearly in agreement with Cruse et al., [9] and Del Principe et al., [8] studies, who found that the expression of CD38 was detected in (40\%) and (36\%) respectively, of their CLL cases. In addition to, Deaglio et al., found that CD38 expression was detected in $(58.92 \%)$ of his studied cases [10]. In contrast, only $(19.5 \%)$ of cases were positive for CD38 expression in Morabito et al., study [7]

In the present study only 4 patients (13.4\%) had monoclonal gamopathy (M-band), the type of the M-band in these patients was IgG-Kappa $(100 \%)$. One patient had diffuse band (3.3\%). This result is in agreement with $\mathrm{Xu}$ et al., [5] who study the prognostic significance of serum immunoglobulin paraprotein in patients with CLL. His study was conducted on 133 consecutive patients with newly diagnosed CLL. Serum immunoglobulins were measured by SPE and IFE. They identified 27 patients with immunoglobulin paraproteinemia from a total of 133 untreated patients with CLL, with a frequency of $20.3 \%$.

Yin and his colleagues [11] examined the sera of 1,053 untreated patients with CLL/SLL by SPE and IFE. They identified 26 IgM paraprotein with a frequency of $(2.47 \%)$. Yin concluded that all
CLL/SLL patients in his study had relatively low levels of serum monoclonal IgM.

Noel et al., reviewed the records of all Mayo Clinic patients seen between January 1971 and July 1984 and found that one hundred patients with CLL and a monoclonal protein in serum or urine were recognized during this period. They reported that $\mathrm{IgG}$ monoclonal proteins predominated in CLL patients with the following distribution: IgG kappa $36 \%$, IgG lambda 15\%, IgM kappa 27\%, IgM lambda $11 \%$, IgA lambda $1 \%$, and free monoclonal light chains in 10\% (kappa in $8 \%$ and lambda in 2\%) [12]. Also Xu et al., identified 27 patients with Ig paraproteinemia (12 patients with IgG paraprotein, 12 patients with IgM paraprotein, 3 patients with both $\operatorname{IgG}$ and $\operatorname{IgM}$ ) from a total of 133 untreated patients with CLL [5]

Guastafierro et al., recorded that in their study on CLL patients, one patient had lambda FLC and IgG lambda simulating a biclonal gammopathy [14]. Also Sanchez et al., suggested that these additional M components may represent biclonal or triclonal lymphoproliferative disorders or the development of a subclone within the original tumor cells because of clonal evolution [13]. The possible explanations of discrepancy in frequency of serum immunoglobulin paraprotein in CLL patients and their prognostic impact might be due to different therapeutic regimens, shorter clinical follow-up and smaller number of patients.

In this study, we found a significant relation between presence of M-band by protein electrophoresis and ZAP 70 positivity. This may indicate that the detection of immunoglobulin paraprotein may be added as a prognostic factor in CLL. Our results is in agreement with $\mathrm{Xu}$ et al., who suggested the possibility of interaction between serum immunoglobulin paraprotein and other known prognostic factors, such as serum level of B2-M, LDH, ZAP70 [5].

\section{Conflict of interest:}

The authors declare no conflict of interest.

\section{References}

1- MORENO C. and E. MONTSERRAT: New prognostic markers in chronic lymphocytic leukemia. Blood Rev.; 22 (4): 211-9, 2008.

2- CAMPO E., S.H. SWERDLOW, N.L. HARRIS, S. PILERI, H. STEIN and E.S. JAFFE: The 2008 WHO classification of lymphoid neoplasms and beyond: evolving concepts and practical applications. Blood; 117 (19): 5019-32, 2011.

3- ZENZ T., S. FROHLING, D. MERTENS, H. DOHNER and S. STILGENBAUER: Moving from prognostic to 
predictive factors in Chronic Lymphocytic Leukaemia (CLL). Best. Pract. Res. Clin. Haematol.; 23 (1): 71-84, 2010.

4- DAMLE R.N., S. TEMBURNI, C. CALISSANO, S. YANCOPOULOS, T. BANAPOUR, C. SISON, S.L. ALLEN, K.R. RAI and N. CHIORAZZI: CD38 expression labels an activated subset within chronic lymphocytic leukemia clones enriched in proliferating B cells. Blood; 110 (9): 3352-9, 2007.

5- XU W., Y.H. WANG, L. FAN, C. FANG, D.X. ZHU, D.M. WANG, C. QIAO, Y.J. WU and J.Y. LI: Prognostic significance of serum immunoglobulin paraprotein in patients with chronic lymphocytic leukemia. Leuk Res.; 35 (8): 1060-5, 2011.

6- BAIN B.J., D. BARNETT, D. LINCH, E. MATUTES, J.T. REILLY and B.S.O.H.: General Haematology Task Force of the British Committee for Standards in Haematology Revised guideline on immunophenotyping in acute leukaemias and chronic lymphoproliferative disorders. Clin. Lab. Haematol.; 24 (1): 1-13, 2002.

7- MORABITO F., R. De FILIPPI, L. LAURENTI, K. ZIRLIK, A.G. RECCHIA, M. GENTILE, E. MORELLI, E. VIGNA, V. GIGLIOTTI, R. CALEMMA, B. AMOROSO, A. NERI, G. CUTRONA, M. FERRARINI, S. MOLICA, G. DEL POETA, C. TRIPODO and A. PINTO: The cumulative amount of serum-free light chain is a strong prognosticator in chronic lymphocytic leukemia. Blood; 118 (24): 6353-61, 2011.

8- DEL PRINCIPE M.I., G. DEL POETA, F. BUCCISANO, L. MAURILLO, A. VENDITTI, A. ZUCCHETTO, R. MARINI, P. NISCOLA, M.A. CONSALVO, C. MAZZONE, L. OTTAVIANI, P. PANETTA, A. BRUNO, R. BOMBEN, G. SUPPO, M. DEGAN, V. GATTEI, P. De FABRITIIS, M. CANTONETTI, F. LO COCO, D. DEL
PRINCIPE and S. AMADORI: Clinical significance of ZAP-70 protein expression in B-cell chronic lymphocytic leukemia. Blood; 108 (3): 853-61, 2006.

9- CRUSE J.M., R.E. LEWIS, R.N. WEBB, C.M. SANDERS and J.L. SUGGS: Zap-70 and CD38 as predictors of IgVH mutation in CLL. Exp. Mol. Pathol.; 83 (3): 459-61, 2007.

10- DEAGLIO S., T. VAISITTI, S. AYDIN, L. BERGUI, G D'ARENA, L. BONELLO, P. OMEDE, M. SCATOLINI, O. JAKSIC, G. CHIORINO, D. EFREMOV and F. MALAVASI: CD38 and ZAP-70 are functionally linked and mark CLL cells with high migratory potential. Blood; 110 (12): 4012-21, 2007.

11- YIN C.C., P. LIN, D.A. CARNEY, B.C. HANDY, G.Z. RASSIDAKIS, J. H. ADMIRAND, M.J. KEATING and L.J. MEDEIROS: Chronic lymphocytic leukemia/small lymphocytic lymphoma associated with IgM paraprotein. Am. J. Clin. Pathol.; 123 (4): 594-602, 2005.

12-NOEL P. and R.A. KYLE: Monoclonal proteins in chronic lymphocytic leukemia. Am. J. Clin. Pathol.; 87 (3): 3858, 1987.

13- SANCHEZ M.L., J. ALMEIDA, D. GONZALEZ, M.A. GARCIA-MARCOS, A. BALANZATEGUI, M.C. LOPEZ-BERGES, J. NOMDEDEU, T. VALLESPI, M. BARBON, A. MARTIN, P. De La FUENTE, G. MARTINNUNEZ, J. FERNANDEZ-CALVO, J.M. HERNANDEZ, J.F. SAN MIGUEL and A. ORFAO: Incidence and clinicobiologic characteristics of leukemic B-cell chronic lymphoproliferative disorders with more than one B-cell clone. Blood; 102 (8): 29947-3002, 2003.

14- GUASTAFIERRO S., M. CELENTANO, C. CUOMO and U. FALCONE: Chronic lymphocytic leukemia with associated lambda-light-chain and IgG lambda paraproteins simulating a biclonal gammopathy. Clin. Lab.; 56 (1112): 577-80, 2010. 


\section{البارا بروتين المناعى اليروي \\ فى مرضى سرطان الدم الليمفاوى المناهين}

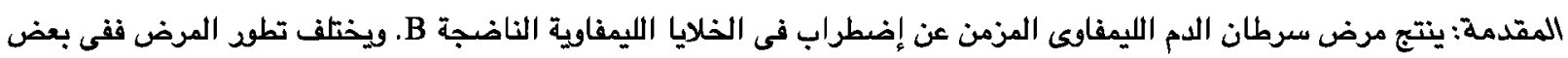

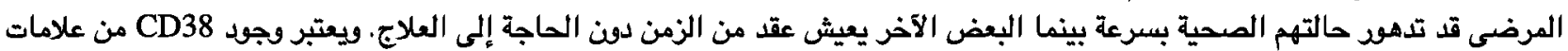

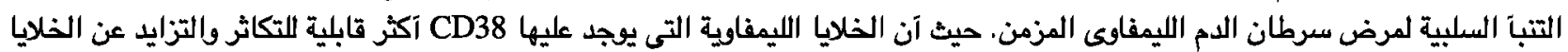

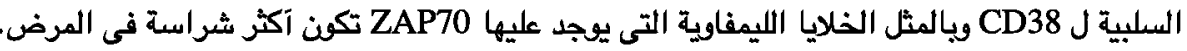

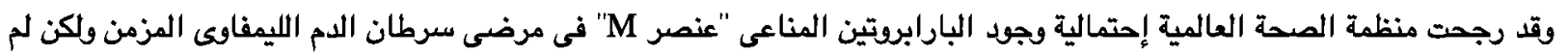

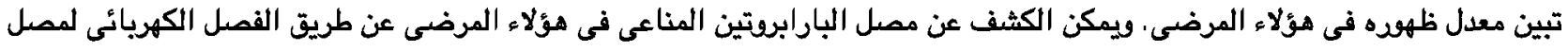

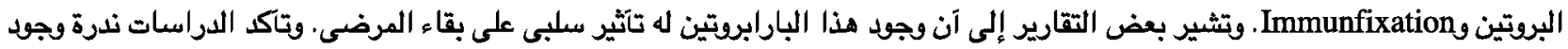

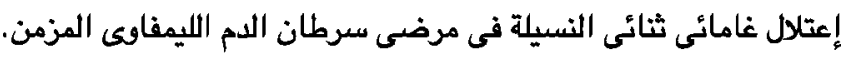

الهدف من هذه الدراسة: تهدف هذه الدراسة إلى الكثف عن البارابروتين المناعى فى مرضى سرطان الدم الليمفاوى المزمن وعلاقته

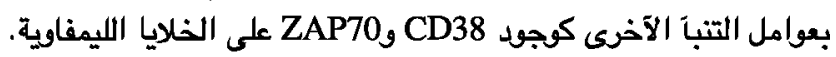

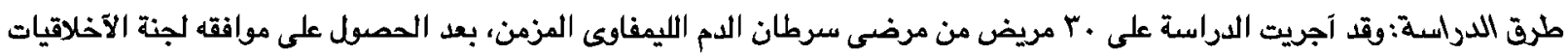

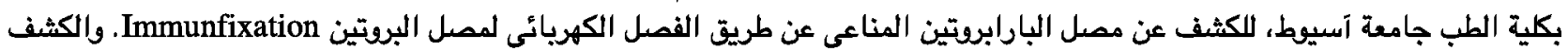

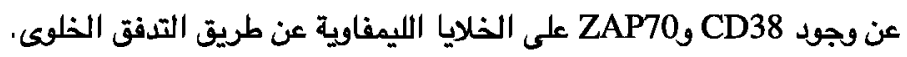

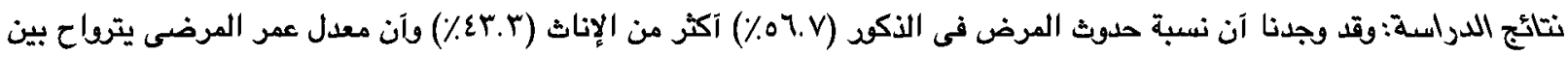

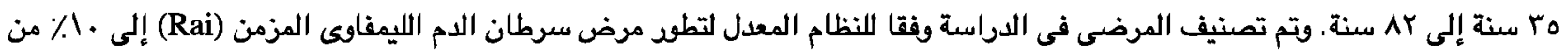

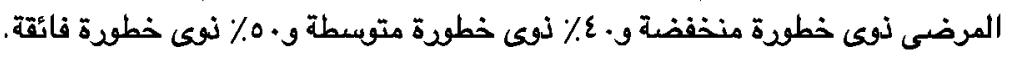

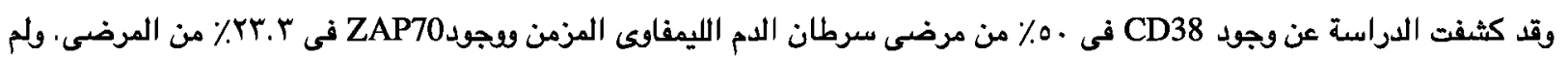
تكن هناك علاقة ذات دلالة إحصائية بين وجو وقد كثفت نتائج الدراسة آيضا آن نسبة البارابروتين المناعى فى مرضى سرطان الدم الليمفاوى المزمن هى ع.باء٪.

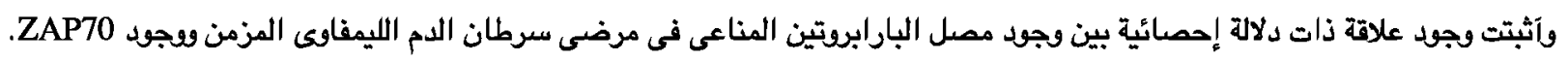

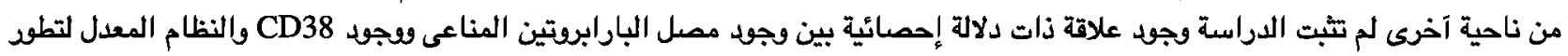

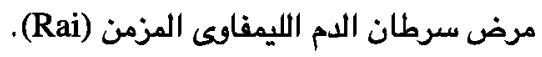

